\title{
Hepatitis C in Argentina: epidemiology and treatment
}

This article was published in the following Dove Press journal:

Hepatic Medicine: Evidence and Research

27 May 2014

Number of times this article has been viewed

\section{Luis Alejandro Gaite \\ Sebastián Marciano \\ Omar Andrés Galdame \\ Adrián Carlos Gadano}

Hepatology Unit, Hospital Italiano de Buenos Aires, Buenos Aires, Argentina

Correspondence: Adrián Carlos Gadano Hepatology Unit, Hospital Italiano de Buenos Aires, 4190 Juan D Perón Highway, Buenos Aires CI I99ABB, Argentina

Tel +54 I| 49590200 ext 5370

Fax +54 II 49590346

Email adrian.gadano@hospitalitaliano. org.ar
Abstract: Hepatitis $\mathrm{C}$ is the leading cause of chronic hepatitis, cirrhosis, and liver cancer in Argentina, where from $1.5 \%$ to $2.5 \%$ of adults are infected. Most of the infections were acquired $30-50$ years ago. It is estimated that more than half of infected individuals are not aware of their infection. Even though the prevalence in blood donors has decreased to $0.45 \%$ at present, many high-prevalence populations still exist, where the reported prevalence ranges from $2.2 \%$ to $7.1 \%$. Therapy is recommended for patients with fibrosis, in order to prevent disease progression, hepatic decompensation, and hepatocellular carcinoma. Great advances were achieved in the treatment of genotype 1 infection since the development and release of boceprevir and telaprevir. When either of these protease inhibitors is associated with peginterferon plus ribavirin, the sustained virological response (SVR) rate improves from $40 \%-50 \%$ to $67 \%-75 \%$. For genotype 2 and 3 infection, treatment with peginterferon plus ribavirin is still the standard of care, with SVR rates of $70 \%-90 \%$. There are significant new antivirals in development, and some of them are close to being released. These drugs will most likely be the future standard of care for all genotypes, and will be incorporated in better-tolerated and highly effective alloral regimes. The impact that these new therapies might have in health-related economics is unpredictable, especially in developing countries. Each country must carefully evaluate the local situation in order to implement proper screening and treatment programs. Difficult-to-treat patients, such as those with decompensated cirrhosis, patients in hemodialysis, and those with other significant comorbidities, might not be able to receive these new therapeutic approaches and their management will remain challenging.

Keywords: hepatitis C, prevalence, transmission, therapeutics, genotype, Latin America

\section{Introduction}

Hepatitis $\mathrm{C}$ virus (HCV) infection is a major public health matter of concern to both industrialized and developing countries. It is the leading cause of chronic hepatitis, cirrhosis, and hepatocellular carcinoma (HCC), as well as the most common indication for liver transplantation in Argentina and many other countries. ${ }^{1,2}$ It is estimated that 180 million people are infected worldwide, ${ }^{3}$ and more than half of them are not aware of their infection. ${ }^{4}$

Hepatitis $\mathrm{C}$ virus is a ribonucleic acid (RNA)-enveloped flavivirus, and there are at least six major HCV genotypes whose prevalence varies geographically. This virus is mainly transmitted by a parenteral route, being the most efficient means of transmission. There are several factors influencing interactions between the host and the $\mathrm{HCV}$; therefore, the clinical picture and natural history are variable for both acute and chronic hepatitis. After acute infection, $75 \%-85 \%$ of patients develop chronic disease. ${ }^{5}$ 
Chronic HCV infection often follows a progressive course, and may ultimately result in cirrhosis, HCC, and the need for liver transplantation. ${ }^{6}$

The HCV genotype determines the treatment selection and is one of the main therapy-response predictors. Some studies suggest that the HCV genotype could have an impact on the natural history of HCV infection. However, this has not been confirmed..$^{7-9}$

The study of pathogenic mechanisms and natural history of the disease is hampered by the absence of adequate animal or cell-culture models. Therefore, most of the studies have been based on observations of infected patients, with different clinical settings and significant geographical heterogeneity. Successful treatment of HCV eradicates infection, reduces hepatic fibrosis and inflammation, and precludes hepatic decompensation. ${ }^{10-12}$ This article focuses on the epidemiology and treatment of HCV in Argentina.

\section{HCV epidemiology in Argentina HCV-prevalence estimation}

The global estimate for the actual prevalence of HCV infection is still associated with some degree of uncertainty. The available data suggest that $\mathrm{HCV}$-infection prevalence is approximately $2.2 \%-3.0 \%$ worldwide (130-170 million people). ${ }^{13}$ Important efforts are being made throughout specific regions to ascertain $\mathrm{HCV}$ prevalence in high-risk populations, blood donors, and healthy volunteers.

Because there are no large-scale general population studies on HCV prevalence in Argentina, available data are based mainly on spontaneous demand studies, blood donors, and specific small communities where seroprevalence was suspected to be high. The main difficulties in obtaining demographic data are related to Argentina's sociocultural, geographic, and economic aspects. Ninety percent of the country's 40 million population is concentrated in a few principal cities, whereas the overall population density is 15 inhabitants $/ \mathrm{km}^{2}$.

In general populations and in studies done on spontaneous demand population, the estimated prevalence is from $1.5 \%$ to $2 \%-2.5 \%$ in adults. ${ }^{14,15}$ Another study showed a prevalence of $0 \%-0.6 \%$ in 18 - to 24 -year-old adults, which is congruent with a lower incidence transmission in young adults. ${ }^{16}$

Some studies performed on specific populations showed much higher prevalence, ranging from $2.2 \%$ to $7.1 \%{ }^{17-20}$ It is suspected that the transmission pattern in these small communities involved injectable material misuse in health community centers, as aggregation of subgenotype clusters was observed (Table 1).
Table I Hepatitis C virus (HCV) prevalence in specific population studies in Argentina

\begin{tabular}{llll}
\hline Study & $\mathbf{n}$ & Prevalence & $\begin{array}{l}\text { HCV genotype } \\
\text { distribution }\end{array}$ \\
\hline Picchio et al $^{18}$ & $\mathrm{I}, 8 \mathrm{I7}$ & $5.6 \%$ & $\mathrm{Ib}: 100 \%$ \\
Golemba et al $^{17}$ & $\mathrm{I}, 814$ & $4.9 \%$ & $\mathrm{Ia}: 7 \% ; \mathrm{Ib}: 89 \% ; 2 \mathrm{a}: 4 \%$ \\
Ramadan $^{19}$ & 452 & $2.2 \%$ & $\mathrm{Ib}: 66.6 \% 2 \mathrm{a}: 33.3 \%$ \\
Mengarelli $^{20}$ & 2,008 & $7.1 \%$ & $\mathrm{I}: 9 \% ; 2: 90 \%$ \\
\hline
\end{tabular}

\section{$\mathrm{HCV}$ prevalence in blood donors}

Blood donors in our country represent a select group. They are mainly men (65\%), do not report risk factors for blood-borne infections, and are mainly young adults. Consequently, they do not represent the general population. ${ }^{21}$ The prevalence of $\mathrm{HCV}$ among blood donors is decreasing (Table 2), ${ }^{21,22}$ and is probably associated with better donor selection, the known lower $\mathrm{HCV}$ prevalence in the younger population, and improvements in diagnostic equipment. With regard to serological tools, new technologies applied in the last few years have contributed to improving detection, thus lowering false-positive results.

\section{$\mathrm{HCV}$ prevalence in high-risk populations} Intravenous drug users

Most patients infected with HCV worldwide acquired the disease through intravenous drug use (IDU). ${ }^{3}$ In Argentina, the prevalence of $\mathrm{HCV}$ in this group is reported to be $54.6 \%$, with a high rate of human immunodeficiency virus (HIV)/ HCV coinfection (88\%). ${ }^{23}$ In the cited study, patients' average age was 30 years, and most of them were male. The IDU incidence is reported to be decreasing because of harmreduction programs.

\section{HCV/HIV coinfection}

Since the introduction of antiretroviral therapy in $\mathrm{HIV}^{+}$ patients, $\mathrm{HCV}$ infection has gained relevance as a cause of morbidity and mortality in this population. In coinfected patients, accelerated fibrosis progression was observed, leading to cirrhosis and its complications in a shorter period compared to HCV-monoinfected patients. ${ }^{24}$

Table 2 Hepatitis $\mathrm{C}$ virus (HCV) prevalence in blood donors by year in Argentina

\begin{tabular}{lll}
\hline Year & HCV prevalence & Total blood donors \\
\hline 1997 & $1.16 \%$ & No data \\
2000 & $0.78 \%$ & 444,182 \\
2004 & $0.67 \%$ & 147,475 \\
2006 & $0.69 \%$ & 442,916 \\
2008 & $0.66 \%$ & 387,361 \\
2010 & $0.43 \%$ & 462,141 \\
\hline
\end{tabular}


Different reports on the $\mathrm{HIV}^{+}$population in our country show a $12 \%-60 \%$ HCV prevalence..$^{25-27}$ Risk factors for infection and genotype distribution are slightly different than in $\mathrm{HCV}$-monoinfected patients. In Argentina, when the route of transmission was studied, IDU was described in $90 \%$ of those coinfected. On the other hand, sexual exposure was reported as the main risk factor in $49 \%$ of women. ${ }^{28}$ Genotype distribution varies in coinfected patients, being HCV genotype $1 \mathrm{a} / \mathrm{c}$ (HCV-G1a/c) responsible for $50 \%$ of all infections, mixed infections in $15.3 \%$, genotype 3 (HCV-G3) in $11.8 \%$, and HCV-G1b in $10.6 \% .^{29,30}$ This trend toward an increased rate of G1a and G3 versus G1b is consistent with a previous study by Findor et al denoting a presumed increase in transmission by IDU in our country. ${ }^{31}$

Furthermore, a 2005 Argentine study showed a 15\% false negative rate of $\mathrm{HCV}$ enzyme-linked immunosorbent assays (ELISAs) in positive HCV polymerase chain reaction (PCR) RT (real time) patients, remarking on the importance of highsensitivity techniques, such as PCR RT or third-generation ELISA, for HCV screening in this group. ${ }^{27}$

\section{Hemodialysis}

The HCV-infection incidence among hemodialysis patients is steadily declining. This is in part due to the decrease in post-transfusion $\mathrm{HCV}$-infection rates, as well as the implementation of transmission-reduction policies in dialysis units.

In Argentina, according to the Chronic Dialysis Registry, $\mathrm{HCV} \mathrm{ELISA}^{+}$reactions in individuals entering hemodialysis have decreased from $2.0 \%$ in 2004 to $1.0 \%$ in 2011 . The global HCV prevalence in 2011 was reported to be $4.9 \%$. The risk of infection rises with time on hemodialysis, being about $38 \% \mathrm{HCV}^{+}$in those hemodialysis patients undergoing 16 or more years of treatment. ${ }^{32}$

\section{Routes of transmission}

HCV infection may spread by several routes: blood transfusions, IDU, nosocomial infections, non-IDU forms of injections, dental procedures, tattooing, and other procedures that involve contact with contaminated blood being the most infective. The routes of transmission vary according to different geographic areas and periods.

The available epidemiological data in Argentina are consistent with most people acquiring $\mathrm{HCV}$ infection approximately 30-50 years ago through blood transfusions or by using non-IDU forms of injections with inadequately sterilized glass syringes. ${ }^{17-20}$ A government registry report on 1,011 HCV-infected patients showed different means of trans- mission in separated age-distributed cohorts. Among people who were born before 1945, the main risk factors for HCV infection were previous surgery (34\%) and transfusion (36\%). For the cohort born after 1965, IDU was the main risk factor. ${ }^{33}$ At present, post-transfusion $\mathrm{HCV}$ infection has decreased significantly, and IDU is the main means of transmission in both the HCV-monoinfected and HCV/HIV-coinfected population. ${ }^{22,23,28}$

Less infective sources, such as non-IDU, sexual routes, and household transmission, have been studied in Argentina. A study reported that $8.9 \%$ of the patients had most likely acquired the infection through intranasal drug use. In the same study, $18.3 \%$ of women and $1.7 \%$ of men had most likely become exposed to HCV through sexual contact. ${ }^{28}$ In a retrospective study performed in 219 infected patients, $25 \%$ reported intranasal drug use, $7 \%$ had had an $\mathrm{HCV}^{+}$ sexual partner, and $0.5 \%$ reported household contact as the most probable means of transmission. Of note, $19 \%$ had no identifiable risk factor. ${ }^{34}$

With regard to vertical transmission of $\mathrm{HCV}$ infection, the main risk factors for $\mathrm{HCV}$ transmission to children are maternal $\mathrm{HCV}$ infection and blood-product transfusion. It has been reported that vertical $\mathrm{HCV}$-infection transmission occurs at birth in about $5 \%$ of children born to an infected mother. ${ }^{35}$ This rate rises in highly viremic patients, as it happens in $\mathrm{HIV} / \mathrm{HCV}$ coinfection, shifting the transmission rate to $19.4 \% .{ }^{36} \mathrm{~A}$ cohort study in Argentina analyzed 48 children under $\mathrm{HCV}$ risk, and described that pediatric $\mathrm{HCV}$ infection was characterized by high viral loads and was independent of both age and route of transmission. It also stated that among 17 perinatal infected children, 16 (94\%) were born to $\mathrm{HCV} /$ HIV-coinfected mothers. ${ }^{37}$

Health care workers are at risk of $\mathrm{HCV}$ infection by percutaneous injuries with disposable syringes, suture needles, and scalpels; the risk of infection after a needlestick accident is $1.8 \%{ }^{38} \mathrm{~A}$ single-center study on 402 health care workers in Argentina found $\mathrm{HCV}-\mathrm{ELISA}^{+}$prevalence of $0.5 \% .{ }^{39}$

\section{Screening for hepatitis C}

The following groups of persons are considered to be at risk of HCV infection, and must be tested:40,41

- persons who have injected or inhaled illicit drugs at least once in their life

- persons with conditions associated with a high prevalence of HCV infection, including:

- persons with HIV infection

- persons with hemophilia

- persons who have ever been on hemodialysis 
- persons with unexplained abnormal aminotransferase levels

- prior recipients of transfusions or organ transplants prior to 1992

- children born to HCV-infected mothers

- health care workers after needlestick injury or mucosal exposure to $\mathrm{HCV}^{+}$blood

- current sexual partners of HCV-infected persons.

The following groups of persons might benefit from HCV screening:

- health care workers

- persons exposed to invasive medical interventions

- those who have undergone unsafe piercing or tattooing practices

- men who have sex with men

- those with multiple sexual partners

- household contacts of patients with HCV.

Universal screening is not formally recommended. However, testing every person at least once could increase the number of undiagnosed patients who might benefit from treatment.

\section{Treatment of HCV}

The natural history of HCV shows that the majority of patients may become chronically infected and will not spontaneously resolve the infection. ${ }^{5}$ About $20 \%$ of chronically infected patients will evolve to cirrhosis within 25-30 years, with an increased risk of hepatic decompensation and HCC. A natural history study on the transfused population performed in our country showed that $21 \%$ of $\mathrm{HCV}^{+}$patients evolved to severe fibrosis 24 years posttransfusion. ${ }^{42}$ Another study from a high$\mathrm{HCV}$-prevalence population in Argentina showed that during a 5-year follow-up period, $40 \%$ of $\mathrm{HCV}$ cirrhotic patients developed hepatic-associated decompensation or HCC. ${ }^{18}$

The goal of HCV treatment is to eradicate the virus and prevent the complications of chronic liver disease. Attaining SVR (sustained viral response) has been associated with decreases in all-cause mortality, liver-related death, need for liver transplantation, HCC, and liver-related complications. ${ }^{10-12}$ Selecting patients for antiviral therapy is based upon various factors. Patient factors include fibrosis stage, probability of adverse events of therapy, and comorbidities, such as chronic kidney disease or psychiatric disease, that may preclude or modify therapy options. Virological factors include mainly the HCV genotype, which determines the treatment strategy: drug selection and treatment duration.

The European Association for the Study of the Liver (EASL) and American Association for the Study of Liver
Diseases (AASLD) guidelines on HCV management have suggested that identifying individuals at risk for progressive $\mathrm{HCV}$ disease by assessing fibrosis stage should prompt an indication of therapy. ${ }^{44}$ Beyond that, any patient who is willing and able to receive therapy should be treated; therapy may be considered in patients after a biopsy proving moderate fibrosis (METAVIR score F2), and mandatory for advanced fibrosis (METAVIR score F3-F4). These are also the stated recommendations on local guidelines. ${ }^{43,44}$ Assessment of fibrosis stage can be achieved either on liver biopsy or noninvasive methods, including transient elastography or serological markers.

For years, the standard of care (SOC) for HCV treatment has been the use of pegylated interferon (PEG) plus ribavirin (RBV). Recently, the SOC on HCV-G1 infection changed, including the addition of protease inhibitor (PI) therapy to the PEG-RBV scheme, with improvements in SVR increasing from $40 \%-50 \%$ to $67 \%-75 \% .{ }^{45,46}$ For HCV-G2 and HCV-G3, PEG plus RBV still remains the SOC, with SVR of about $70 \%-90 \% .^{40,47}$

Argentina's health care system is composed of three main groups:

- patients without any health insurance (they are assisted by the public health system)

- patients with private health insurance

- patients assisted by social security.

HCV treatment-related costs are always the responsibility of the public health system, which ultimately reimburses private insurance and the social security system. However, since this has been recently implemented, logistic barriers exist that make accessibility to treatment of patients without any health insurance difficult. The national program of viral hepatitis is actively working to improve this issue.

In our country, treatment indication of $\mathrm{HCV}$ follows our local guidelines, which are in line with the AASLD and EASL ones. However, real-life studies reflecting how patients are ultimately treated are lacking.

\section{Predicting treatment response}

The HCV genotype is the main therapy-response predictor, with HCV-G2 the most sensitive to PEG-RBV therapy. HCV-G3 and HCV-G1 follow in order of SVR rate. With a new SOC for HCV-G1 therapy, HCV-G1 and HCV-G3 could achieve similar SVR rates. ${ }^{8}$ Other predictive factors of response are useful to estimate SVR, and are different according to the genotype.

\section{Genotype I}

Pretreatment response predictors for HCV-G1 infection include low basal viral load, absence of fibrosis, and 
Caucasian race. The relationship between IFNL3 (previously interleukin [IL]-28B) polymorphism and response to treatment was reviewed recently. ${ }^{48}$ A retrospective study on 102 Latin American patients treated with PEG-RBV in Argentina found that IFNL3 rs12979860-CC and rs8099917TT genotypes were associated with SVR rates of $64 \%$ and $55 \%$, respectively, marking its use as an important tool for planning therapy. ${ }^{49}$ Other factors such as age, sex, presence of steatosis, obesity, and diabetes mellitus follow in order of importance.

With regard to PI-based therapy, on-treatment main predictors of response are virological: rapid virologic response (RVR) and extended RVR. In addition, SVR rate is reported to be $7 \%-10 \%$ higher for HCV-G1b than HCV-G1a, explained by differences in genetic barriers to the PI.

\section{Genotype 2}

As reported in other genotypes, fibrosis stage decreases with SVR rate. It has been reported in a real-life study on HCV-G2 patients that the presence of cirrhosis decreased SVR rates by $11 \%$ and increased virological relapse by $5 \% .{ }^{50}$ On the other hand, steatosis and basal viral load do not strongly predict SVR in this group of patients. ${ }^{51}$ In HCV-G2, the IFNL3 polymorphism seems to only predict SVR in patients who do not achieve RVR. ${ }^{52}$

\section{Genotype 3}

There is enough evidence to consider HCV-G3 separately from $\mathrm{HCV}-\mathrm{G} 2$ when evaluating treatment-related aspects. ${ }^{8,53}$ Pretreatment variables that predict SVR in HCV-G3 patients are fibrosis stage ( $\leq \mathrm{F} 2$ ), age less than 40 years, white ethnicity, female sex, basal viral load below 400,000 IU/mL, weight less than $85 \mathrm{~kg}$, coffee consumption, and absence of steatosis. As in G2, the IFNL3 polymorphism seems to only predict RVS in patients who do not achieve RVR. ${ }^{52,54}$

\section{Genotype I treatment}

The recent development of direct-acting antiviral agents changed the current treatment of HCV-G1. ${ }^{55}$ Furthermore, a large number of compounds are being studied, including five distinct drug classes. These are NS3 PIs, NS5B polymerase inhibitors, NS5A replication-complex inhibitors, and interferon and host-target agents, including microRNA-122 and cyclophilin inhibitors. ${ }^{56}$ These pharmacological developments provide the motivation to move novel treatments into clinical investigation. As a result, a large number of drugs are to become available in clinical practice in the next few years, bringing changes to current therapeutic regimens.
Until these new treatments are released, the decision to treat patients infected with HCV-G1 with the currently approved drugs or to wait for future options has to be made, taking into account fibrosis stage, the patient's wish to be treated, and individual patient characteristics.

According to recent guidelines, patients with HCV-G1 infection should be treated with PEG, RBV, and either boceprevir (BOC) or telaprevir (TVR). ${ }^{55}$ With this approach, SVR rates increase from $40 \%$ to $67 \%-75 \%{ }^{45,46}$ Despite their clear benefits on SVR, these schemes have increased the rates of adverse events and costs substantially. Real-life studies report discontinuation rates of up to $6 \%-12 \% .{ }^{57,58}$ With regard to BOC- or TVR-based therapy cost-effectiveness, some studies remark that treating patients with BOC or TVR therapy is cost-effective in years of life gained. ${ }^{59,60}$ Definitely, these first-generation PIs will be replaced by simpler ones and better-tolerated and even interferon-free strategies. In the meantime, it is of crucial importance to understand the optimal use of these drugs. Unlike PEG-RBV therapy, these drugs may induce resistance. ${ }^{61,62}$ Therefore on-therapy viral kinetics must be carefully determined, and when indicated, therapy should be stopped (Table 3). ${ }^{44,55}$

BOC and TVR therapy are indicated for both naïve and experienced patients. SVR rates from registry studies showed more benefits on relapse and naïve patients treated, and lower efficacy on partial and null responders. Partial and null responders with advanced METAVIR-F4 fibrosis had the lowest chance of SVR (about 35\%) in these studies. ${ }^{63,64}$

In July 2012, in Argentina, the Administración Nacional de Medicamentos, Alimentos y Tecnología Médica drugregulatory authority formally approved BOC and TVR for HCV-G1 therapy. Since then, the Asociación Argentina para el Estudio de las Enfermedades del Hígado has updated the local guidelines on HCV-G1 treatment. ${ }^{44}$ These local guidelines, in line with the EASL and AASLD ones, state that first-line therapy in $\mathrm{HCV}-\mathrm{G} 1$ patients is BOC or TVR in combination with PEG-RBV.

Table 3 Telaprevir and boceprevir stopping rules

\begin{tabular}{lll}
\hline & HCV-RNA-PCR & Action \\
\hline Telaprevir (TVR) & & \\
Week 4 & $>1,000 \mathrm{IU} / \mathrm{mL}$ & Discontinue TVR and PEG-RBV \\
Week I2 & $>1,000 \mathrm{IU} / \mathrm{mL}$ & Discontinue TVR and PEG-RBV \\
Week 24 & Detectable & Discontinue PEG-RBV \\
Boceprevir (BOC) & & \\
Week I2 & $\geq 100 \mathrm{IU} / \mathrm{mL}$ & Discontinue BOC and PEG-RBV \\
Week 24 & Detectable & Discontinue BOC and PEG-RBV \\
\hline
\end{tabular}

Note: Data from Silva et $\mathrm{al}^{45}$ and Ghany et al. ${ }^{56}$

Abbreviations: HCV-RNA-PCR, hepatitis $C$ virus ribonucleic acid polymerase chain reaction; $\mathrm{PEG}$, pegylated interferon; RBV, ribavirin. 
Even though BOC/TVR + PEG-RBV has not been formally approved for use, some specific HCV-G1-infected patients, such as those co-infected with hepatitis B and/or HIV and transplant recipients, might benefit from this triple therapy ${ }^{65-70}$ On the other hand, in patients with advanced cirrhosis, on hemodialysis replacement therapy, or with other significant comorbidities, these therapeutic schemes are contraindicated. Finally PEG-RBV without BOC or TVR could be considered in a limited number of patients with favorable predictors of response.

\section{Genotype 2 treatment}

HCV genotype 2 has a worldwide distribution, being the third-most prevalent genotype in most countries. It is particularly prevalent in some Latin American countries, like Argentina and Venezuela, where its prevalence ranges from $25 \%$ to $34 \% .{ }^{14}$ The SOC treatment with PEG-RBV for 24 weeks achieves SVR in up to $95 \%$ of chronic HCV genotype 2 -infected patients, as this is the easiest genotype to treat with the current approved agents. ${ }^{43}$

Assessment of RVR at week 4 could identify candidates to shorten therapy. Chronic HCV genotype 2 patients with favorable basal and on-treatment predictors of response to PEG plus RBV could be treated for shorter periods, thus reducing costs and toxicity. ${ }^{71}$ In this instance, weight-based RBV dosing is crucial to achieve similar SVR rates in short (16-week) regimens. ${ }^{50}$ On the other hand, even though slow responders not achieving RVR but with early virologicalresponse at week 12 are infrequent, they still could benefit from prolonging the treatment to 48 or even 72 weeks..$^{43}$

\section{Genotype 3 treatment}

According to recent guidelines, PEG-RBV therapy for 24 weeks is the established SOC for chronic HCV-G3 infection. ${ }^{15,37,43,40,72}$ However, difficulties in treating HCV-G3 still exist. Recently, SVR rates with this approach were shown to be lower in HCV-G3 in relation to HCV-G2. ${ }^{73}$ Furthermore, optimal duration and dosage have not been clearly established for those rapid and slow responders. A recent meta-analysis in response-guided treatment demonstrated that treatment with PEG plus RBV (weight-based) during 16 weeks in patients with RVR resulted in SVR rates of $76.3 \%$ in HCV-G3 infection. ${ }^{74}$ Weight-based RBV dosing and close on-treatment viral kinetics are crucial to achieve the best results. It is not recommended to reduce the treatment duration in a fixed way, and it should be individualized. Some patients who do not achieve RVR would benefit from extending therapy for 48 weeks or even longer periods. ${ }^{75}$

\section{Future perspectives}

Great advances have been achieved in the last few years in the treatment of HCV-G1. Moreover, highly effective all-oral regimens will be available in the near future for all genotypes. $^{76-78}$

The most promising drugs that might be released in forthcoming years are sofosbuvir, daclatasvir, asunaprevir, and simeprevir, among others. ${ }^{76,79-81}$ The impact that these new therapies might have on health-related economics is unpredictable, especially in developing countries. Difficult-to-treat patients, such as those with decompensated cirrhosis, on hemodialysis, and with significant comorbidities, might not be able to receive these new therapeutic approaches, and their management will still be challenging.

\section{Discussion}

Global efforts to control HCV disease are being made. HCV infection is a major cause of liver disease worldwide, and will be a potential cause of substantial morbidity and mortality in the future. Overall, $25 \%$ of chronically infected patients will develop cirrhosis, and a significant proportion could develop hepatocellular carcinoma. ${ }^{6}$ Robust epidemiological data in Latin America is missing. In Argentina, HCV prevalence is reported to be around $2 \%{ }^{82}$ However, small samples of specific populations show higher prevalence ranging from $2 \%$ to $7 \%$. In intravenous drug users, sexual workers, and patients on hemodialysis, prevalence is between $5 \%$ to $50 \%$. It is of major concern that most HCV-positive patients might be unaware of their infection.

Significant improvement in SVR rates for HCV-G1 therapy has been observed since the approval of BOC and TVR. Response-guided therapy results in shortening treatment duration to 24-28 weeks in a substantial proportion of patients. However, this strategy has limitations in previous partial and null responders, patients with advanced fibrosis, and difficult-to-treat patients, such as transplant recipients, HIV/HCV-coinfected patients, or patients on hemodialysis.

For HCV-G2 and HCV-G3 infection, acceptable SVR rates with PEG-RBV are being achieved. However, a proportion of patients would benefit from new therapeutic strategies, particularly difficult-to-treat patients and prior nonresponders. Great expectation exists for the approval of new therapeutic strategies, with greater SVR rates and better safety profiles.

Chronic HCV will most likely turn into an easier-to-treat disease. This could have a significantly favorable impact on patients, but also an unpredictable impact on physicians and on health-related economics. Each country must carefully 
evaluate the situation in order to implement proper screening and treatment programs.

\section{Disclosure}

ACG has received fees as a member of clinical trials, advisory boards, and/or speaker for the following pharmaceutical companies: GlaxoSmithKline, Bristol-Myers Squibb, Novartis, Gilead, Janssen, MSD (Merck), and AbbVie. LAG, $\mathrm{SM}$, and OAG report no conflicts of interest in this work.

\section{References}

1. Murray KF, Carithers RL Jr. AASLD practice guidelines: evaluation of the patient for liver transplantation. Hepatology. 2005;41(6):1407-1432.

2. Fassio E, Díaz S, Santa C, et al. Etiology of hepatocellular carcinoma in Latin America: a prospective, multicenter, international study. Ann Hepatol. 2010;9(1):63-69.

3. Shepard CW, Finelli L, Alter MJ. Global epidemiology of hepatitis C virus infection. Lancet Infect Dis. 2005;5(9):558-567.

4. Denniston MM, Klevens RM, McQuillan GM, Jiles RB. Awareness of infection, knowledge of hepatitis $\mathrm{C}$, and medical follow-up among individuals testing positive for hepatitis C: National Health and Nutrition Examination Survey 2001-2008. Hepatology. 2012;55(6):1652-1661.

5. Afdhal NH. The natural history of hepatitis C. Semin Liver Dis. 2004; 24 Suppl 2:3-8.

6. Chen SL, Morgan TR. The natural history of hepatitis $\mathrm{C}$ virus (HCV) infection. Int J Med Sci. 2006;3(2):47-52.

7. Kobayashi M, Tanaka E, Sodeyama T, Urushihara A, Matsumoto A, Kiyosawa K. The natural course of chronic hepatitis C: a comparison between patients with genotypes 1 and 2 hepatitis $\mathrm{C}$ viruses. Hepatology. 1996;23(4):695-699.

8. Tapper EB, Afdhal NH. Is 3 the new 1: perspectives on virology, natural history and treatment for hepatitis $\mathrm{C}$ genotype 3. JViral Hepat. 2013;20(10):669-677.

9. Poynard T, Ratziu V, Charlotte F, Goodman Z, McHutchison J, Albrecht J. Rates and risk factors of liver fibrosis progression in patients with chronic hepatitis C. Hepatol. 2001;34(5):730-739.

10. Backus LI, Boothroyd DB, Phillips BR, Belperio P, Halloran J, Mole LA. A sustained virologic response reduces risk of all-cause mortality in patients with hepatitis C. Clin Gastroenterol Hepatol. 2011;9(6):509-516. e1.

11. Morgan TR, Ghany MG, Kim HY, et al. Outcome of sustained virological responders with histologically advanced chronic hepatitis $\mathrm{C}$. Hepatology. 2010;52(3):833-844.

12. Cardoso AC, Moucari R, Figueiredo-Mendes C, et al. Impact of peginterferon and ribavirin therapy on hepatocellular carcinoma: incidence and survival in hepatitis $\mathrm{C}$ patients with advanced fibrosis. J Hepatol. 2010;52(5):652-657.

13. Lavanchy D. The global burden of hepatitis C. Liver Int. 2009; 29 Suppl 1:74-81.

14. Kershenobich D, Razavi HA, Sánchez-Avila JF, et al. Trends and projections of hepatitis C virus epidemiology in Latin America. Liver Int. 2011;31 Suppl 2:18-29.

15. Fassio E, Schroder T. [Statement of the Argentinian Consensus on Hepatitis C 2007]. Acta Gastroenterol Latinoam. 2008;38(1):56-74. Spanish.

16. Fay F. Prevalencia de marcadores de $\mathrm{HCV}$ y $\mathrm{HBV}$ en aspirantes a servicio militar voluntario de la provincia de Santa Fe. Concurrentes al comando del segundo Cuerpo de Ejército Argentino con asiento en Rosario [Prevalence of HCV and HBV markers in voluntary applicants to military service in the province of Santa Fe. Concurrent to the command of the second Argentine Army Corps with headquarters in Rosario]. Poster presented at: Congreso Argentino de Hepatologia. Buenos Aires; June 2005. Spanish.
17. Golemba MD, Di Lello FA, Bessone F, et al. High prevalence of hepatitis $\mathrm{C}$ virus genotype $1 \mathrm{~b}$ infection in a small town of Argentina. Phylogenetic and Bayesian coalescent analysis. PloS One. 2010;5(1): e8751.

18. Picchio GR, Bare PC, Descalzi VI, et al. High prevalence of infection with a single hepatitis $\mathrm{C}$ virus genotype in a small rural community of Argentina. Liver Int. 2006;26(6):660-665.

19. Ramadan A. Prevalencia de infección por HCV en Rufino, Santa Fe [Prevalence of HCV infection in Rufino, Santa Fe]. Poster presented at: Congreso Argentino de Gastroenterología; Buenos Aires; 2-5 Sept 2006. Spanish.

20. Mengarelli S. ¿Por qué el virus C en Cruz del Eje? [Why HCV in Cruz del Eje?]. Poster presented at: Congreso Argentino de Gastroenterologia; Buenos Aires; 2-5 Sept 2006. Spanish.

21. Maschio M. Plan Nacional de Sangre: Avances y Lineas de Accion. Buenos Aires: Ministerio de Salud de la Nación; 2012. Available from: http://hepatitisviral.com.ar/presentaciones/reunion21/martes 1/ PNS_Hepatitis.ppt. Accessed January 28, 2014.

22. Fay O, Rey J, Vladimirsky S. Epidemiology of HCV infection in Argentina. Acta Gastroenterol Latinoam. 2006;36 Suppl 1:S10-S12; discussion S74-S82.

23. Weissenbacher M, Rossi D, Radulich G, et al. High seroprevalence of bloodborne viruses among street-recruited injection drug users from Buenos Aires, Argentina. Clin Infect Dis. 2003;37 Suppl 5: S348-S352.

24. Martinez-Sierra C, Arizcorreta A, Díaz F, et al. Progression of chronic hepatitis $\mathrm{C}$ to liver fibrosis and cirrhosis in patients coinfected with hepatitis $\mathrm{C}$ virus and human immunodeficiency virus. Clin Infect Dis. 2003;36(4):491-498.

25. Fainboim H, González J, Fassio E, et al. Prevalence of hepatitis viruses in an anti-human immunodeficiency virus-positive population from Argentina. A multicentre study. J Viral Hepat. 1999;6(1):53-57.

26. Ré V, Gallego S, Farías A, et al. Hepatitis C and HIV coinfection in central region of Argentina: prevalence, genotype characterization and risk factors. Enferm Infecc Microbiol Clin. 2008;26(7):423-425.

27. Fay F. Prevalencia de infección por HCV en pacientes infectados con $\mathrm{HIV}$ en una provincia Argentina: distribución de genotipos del HCV en pacientes coinfectados de distintas poblaciones de riesgo [Prevalence of $\mathrm{HCV}$ infection in HIV-infected patients in a Argentina province: distribution of HCV genotype in coinfected patients in different risk populations]. Acta Gastroenterol Latinoam. 2005;35(2):61. Spanish.

28. Fassio E, Landeira G, Longo C, Domínguez N, Alvarez E, Gualano G. Risk factors for infection in chronic hepatitis $\mathrm{C}$ : a high prevalence of sexual exposure among human immunodeficiency virus-coinfected women. Hepatology. 2011;54(1):379.

29. Quarleri JF, Bolcic FM, Bouzas MB, et al. HCV genotype distribution among HIV co-infected individuals in Argentina: relationship with host and viral factors. Acta Gastroenterol Latinoam. 2007;37(2):76-83.

30. Bolcic F, Laufer N, Trinchero J, Jones LR, Quarleri J. A clustering phenomenon among HCV-1a strains among patients coinfected with HIV from Buenos Aires, Argentina. J Med Virol. 2012;84(4):570-581.

31. Findor JA, Sordá JA, Daruich J, et al. Distribution of the genotypes of hepatitis $\mathrm{C}$ virus in intravenous drug addicts in Argentina. Medicina (B Aires). 1999;59(1):49-54.

32. Registro Argentino de Diálisis Crónica San-Incucai 2011 [press release]. Sociedad Argentina de Nefrología e Instituto Nacional Central Único Coordinador de Ablación e Implante [Argentine Chronic Dialysis Registry. SAN-INCUCAI 2011]. 2012. Available from: http://san.org.ar/new/ docs/REGISTRO_ARGENTINO_DE_DIALISIS_CRONICA_2011_ INFORME_COMPLETO.pdf. Accessed April 8, 2014. Spanish.

33. Vladimirsky S. Análisis de registros y notificaciones de pacientes con Hepatitis C en dos módulos del Sistema Nacional de Vigilancia de la Salud: Unidades Centinela y C2: Período 2007-2011 [Analysis of records and reports of $\mathrm{HCV}$ patients in two modules of the National Health Surveillance: Sentinel Units and C2: Period 2007-2011]. Poster presented at: Congreso Argentino de Hepatología. Buenos Aires; 6-8 July 2013. Spanish. 
34. Arzeno M. Características clínicas - epidemiológicas de pacientes con hepatitis C [Clinical features and epidemiology of patients with $\mathrm{HCV}$ ]. Poster presented at: Congreso Argentino de Gastroenterología. Mar del Plata; 1-4 October 2009. Spanish.

35. Ohto H, Terazawa S, Sasaki N, et al. Transmission of hepatitis C virus from mothers to infants. The Vertical Transmission of Hepatitis C Virus Collaborative Study Group. N Engl J Med. 1994;330(11):744-750.

36. Roberts EA, Yeung L. Maternal-infant transmission of hepatitis $\mathrm{C}$ virus infection. Hepatology. 2002;36(5 Suppl 1):S106-S113.

37. Gismondi MI, Turazza EI, Grinstein S, Galoppo MC, Preciado MV. Hepatitis $\mathrm{C}$ virus infection in infants and children from Argentina. J Clin Microbiol. 2004;42(3):1199-1202.

38. Preboth M. PHS guidelines for management of occupational exposure to HBV, HCV and HIV: HIV postexposure prophylaxis regimens. Am Fam Physician. 2002;65(2):322, 324-325.

39. Scandizzo E, Loudet S, Varpukevicius G. Prevalencia de anticuerpos para virus de hepatitis $\mathrm{B}$ y $\mathrm{C}$ en trabajadores que se incorporan a un hospital de alta complejidad [Prevalence of antibodies to hepatitis $\mathrm{B}$ and $\mathrm{C}$ virus in workers entering a hospital]. Acta Gastroenterol Latinoam. 2012; 42 Suppl:S8. Spanish.

40. Ghany MG, Strader DB, Thomas DL, Seeff LB. Diagnosis, management, and treatment of hepatitis C: an update. Hepatology. 2009;49(4): 1335-1374.

41. Asociación Argentina para el Estudio de las Enfermedades del Hígado. Consenso Argentino de Hepatitis C 2013. Buenos Aires: AAEEH; 2013. Available from: http://aaeeh.org.ar/docs/libro_resumenes_consenso. pdf. Accessed January 28, 2014.

42. Reggiardo MV, Fay F, Tanno M, et al. Natural history of hepatitis C virus infection in a cohort of asymptomatic post-transfused subjects. Ann Hepatol. 2012;11(5):658-666.

43. European Association for the Study of the Liver. EASL Clinical Practice Guidelines: management of hepatitis C virus infection. $J$ Hepatol. 2011;55(2):245-264.

44. Silva MO, Ridruejo E, Galdame O, et al. [Recommendations for the treatment of chronic genotype 1 hepatitis $\mathrm{C}$ virus infection]. Acta Gastroenterol Latinoam. 2012;42(3):234-249. Spanish.

45. Poordad F, McCone J Jr, Bacon BR, et al. Boceprevir for untreated chronic HCV genotype 1 infection. N Engl J Med. 2011;364(13): 1195-1206.

46. Jacobson IM, McHutchison JG, Dusheiko G, et al. Telaprevir for previously untreated chronic hepatitis $\mathrm{C}$ virus infection. $N$ Engl $\mathrm{J}$ Med. 2011;364(25):2405-2416.

47. Fried MW, Shiffman ML, Reddy KR, et al. Peginterferon alfa-2a plus ribavirin for chronic hepatitis $\mathrm{C}$ virus infection. $N$ Engl J Med. 2002;347(13):975-982.

48. Estrabaud E, Vidaud M, Marcellin P, Asselah T. Genomics and HCV infection: progression of fibrosis and treatment response. $J$ Hepatol. 2012;57(5):1110-1125.

49. Ridruejo E, Solano A, Marciano S, et al. Genetic variation in interleukin28B predicts SVR in hepatitis C genotype 1 Argentine patients treated with PEG IFN and ribavirin. Ann Hepatol. 2011;10(4):452-457.

50. Marcellin P, Cheinquer H, Curescu M, et al. High sustained virologic response rates in rapid virologic response patients in the large real-world PROPHESYS cohort confirm results from randomized clinical trials. Hepatology. 2012;56(6):2039-2050.

51. Grassi E, Aghemo A. How to optimize HCV therapy in genotype 2 patients. Liver Int. 2013;33 Suppl 1:35-40.

52. Mangia A, Thompson AJ, Santoro R, et al. An IL28B polymorphism determines treatment response of hepatitis $\mathrm{C}$ virus genotype 2 or 3 patients who do not achieve a rapid virologic response. Gastroenterology. 2010;139(3):821-827, 827.e1.

53. Mangia A, Mottola L, Piazzolla V. Update on the treatment of patients with non-genotype 1 hepatitis $\mathrm{C}$ virus infection. Clin Infect Dis. 2013;56(9):1294-1300.

54. Lindh M, Lagging M, Färkkilä M, et al. Interleukin 28B gene variation at rs 12979860 determines early viral kinetics during treatment in patients carrying genotypes 2 or 3 of hepatitis C virus. J Infect Dis. 2011;203(12):1748-1752
55. Ghany MG, Nelson DR, Strader DB, Thomas DL, Seeff LB. An update on treatment of genotype 1 chronic hepatitis C virus infection: 2011 practice guideline by the American Association for the Study of Liver Diseases. Hepatology. 2011;54(4):1433-1444.

56. Farnik H, Zeuzem S. New antiviral therapies in the management of HCV infection. Antivir Ther. 2012;17(5):771-783.

57. D'Ambrosio R, Colombo M. Safety of direct antiviral agents in real life. Dig Liver Disease. 2013;45 Suppl 5:S363-S366.

58. Hézode C, Fontaine H, Dorival C, et al. Triple therapy in treatmentexperienced patients with $\mathrm{HCV}$-cirrhosis in a multicentre cohort of the French Early Access Programme (ANRS CO20-CUPIC)-NCT01514890. J Hepatol. 2013;59(3):434-441.

59. Camma C, Petta S, Enea M, et al. Cost-effectiveness of boceprevir or telaprevir for untreated patients with genotype 1 chronic hepatitis $\mathrm{C}$. Hepatology. 2012;56(3):850-860.

60. Camma C, Petta S, Cabibbo G, et al. Cost-effectiveness of boceprevir or telaprevir for previously treated patients with genotype 1 chronic hepatitis C. J Hepatol. 2013;59(4):658-666.

61. Romano KP, Ali A, Aydin C, et al. The molecular basis of drug resistance against hepatitis $\mathrm{C}$ virus NS3/4A protease inhibitors. PLoS Pathog. 2012;8(7):e1002832.

62. Halfon P, Locarnini S. Hepatitis $\mathrm{C}$ virus resistance to protease inhibitors. J Hepatol. 2011;55(1):192-206.

63. Bacon BR, Gordon SC, Lawitz E, et al. Boceprevir for previously treated chronic HCV genotype 1 infection. N Engl J Med. 2011;364(13): 1207-1217.

64. Zeuzem S, Andreone P, Pol S, et al. Telaprevir for retreatment of HCV infection. N Engl J Med. 2011;364(25):2417-2428.

65. Sulkowski MS. HCV therapy in HIV-infected patients. Liver Int. 2013;33 Suppl 1:63-67.

66. Sulkowski M, Pol S, Mallolas J, et al. Boceprevir versus placebo with pegylated interferon alfa- $2 b$ and ribavirin for treatment of hepatitis $C$ virus genotype 1 in patients with HIV: a randomised, double-blind, controlled phase 2 trial. Lancet Infect Dis. 2013;13(7):597-605.

67. Martel-Laferrière V, Brinkley S, Bichoupan K, et al. Virological response rates for telaprevir-based hepatitis $\mathrm{C}$ triple therapy in patients with and without HIV coinfection. HIV Med. 2014;15(2):108-115.

68. Macías J, Rivero A. Safety and efficacy of telaprevir in patients with HIV and hepatitis C virus coinfection. Enferm Infecc Microbiol Clin. 2013;31 Suppl 3:33-36.

69. Lacombe K, Valin N, Stitou H, et al. Efficacy and tolerance of telaprevir in HIV-hepatitis $\mathrm{C}$ virus genotype 1-coinfected patients failing previous antihepatitis $\mathrm{C}$ virus therapy: 24-week results. AIDS. 2013;27(8):1356-1359.

70. Coilly A, Roche B, Dumortier J, et al. Safety and efficacy of protease inhibitors to treat hepatitis $\mathrm{C}$ after liver transplantation: a multicenter experience. $J$ Hepatol. 2014;60(1):78-86.

71. Mangia A, Santoro R, Minerva N, et al. Peginterferon alfa-2b and ribavirin for 12 vs 24 weeks in HCV genotype 2 or 3. N Engl J Med. 2005;352(25):2609-2617.

72. Latin American Association for the Study of the Liver. Latin American Association for the Study of the Liver Practice Guidelines. Diagnosis, management, and treatment of hepatitis C. Ann Hepatol. 2010; Suppl 9:8-26.

73. Shiffman ML, Suter F, Bacon BR, et al. Peginterferon alfa-2a and ribavirin for 16 or 24 weeks in HCV genotype 2 or 3. N Engl J Med. 2007;357(2):124-134.

74. Di Martino V, Richou C, Cervoni JP, et al. Response-guided peginterferon plus ribavirin treatment duration in chronic hepatitis $C$ : meta-analyses of randomized, controlled trials and implications for the future. Hepatology. 2011;54(3):789-800.

75. Sarin SK, Kumar CK. Treatment of patients with genotype 3 chronic hepatitis C - current and future therapies. Liver Int. 2012;32 Suppl 1: 141-145.

76. Everson GT, Sims K, Rodriguez-Torres M. An interferon-free, ribavirinfree 12-week regimen of daclatasvir, asunaprevir, and BMS-791325 yielded SVR 4 of $94 \%$ in treatment-naiive patients with genotype 1 chronic hepatitis C virus infection. Gastroenterology. 2014;146(2):420-429. 
77. Everson G, Sims K, Rodriguez-Torres M. Interim analysis of an interferon (IFN)- and ribavirin (RBV)-free regimen of daclatasvir (DCV), asunaprevir (ASV), and BMS-791325 in treatment-naive, hepatitis C virus genotype 1-infected patients. Poster presented at: 48th Annual Meeting of the European Association for the Study of the Liver; April 24-28, 2013; Amsterdam, Netherlands.

78. Kowdley KV, Lawitz E, Poordad F. Safety and efficacy of interferon-free regimens of ABT-450/r, ABT- 267, ABT-333 +/-ribavirin in patients with chronic HCV GT1 infection: results from the AVIATOR study. Poster presented at: 48th Annual Meeting of the European Association for the Study of the Liver; April 24-28, 2013; Amsterdam, Netherlands.

79. Lawitz E, Mangia A, Wyles D, et al. Sofosbuvir for previously untreated chronic hepatitis C infection. N Engl J Med. 2013;368(20):1878-1887.
80. Jacobson IM, Gordon SC, Kowdley KV, et al. Sofosbuvir for hepatitis C genotype 2 or 3 in patients without treatment options. $N$ Engl J Med. 2013;368(20):1867-1877.

81. Lawitz E, Ghalib G, Rodriguez-Torres M. Suppression of viral load through 4 weeks post-treatment results of a once-daily regimen of simeprevir + sofosbuvir with or without ribavirin in hepatitis $\mathrm{C}$ virus GT 1 null responders. Poster presented at: 20th Conference on Retroviruses and Opportunistic Infections; March 3-6, 2013; Atlanta, GA.

82. Méndez-Sánchez N, Guitiérrez-Grobe Y, Kobashi-Margáin R. Epidemiology of HCV infection in Latin America. Ann Hepatol. 2010;9(S1):S27-S29.

\section{Publish your work in this journal}

Hepatic Medicine: Evidence and Research is an international, peerreviewed, open access journal covering all aspects of adult and pediatric hepatology in the clinic and laboratory including the following topics: Pathology, pathophysiology of hepatic disease; Investigation and treatment of hepatic disease; Pharmacology of drugs used for

\section{Dovepress}

the treatment of hepatic disease. Issues of patient safety and quality of care will also be considered. The manuscript management system is completely online and includes a very quick and fair peer-review system, which is all easy to use. Visit http://www.dovepress.com/ testimonials.php to read real quotes from published authors.

Submit your manuscript here: http://www.dovepress.com/hepatic-medicine-evidence-and-research-journal 